\title{
nature
}

5 August 2004 Volume 430 Issue no 7000

\section{On the campaign trail}

The use and abuse of science is emerging as an issue in the US presidential election. Researchers should seize an opportunity to make their voices heard, whatever their political persuasion.

$\mathrm{L}$ ast week's Democratic National Convention in Boston was all about projecting an image of presidential candidate John Kerry that was designed to resonate with undecided voters. We were given Kerry the family man and Kerry the war hero - "reporting for duty" as the next commander-in-chief. But another character also made a cameo appearance: Kerry the friend of science.

Among the star speakers at the convention was Ron Reagan, who argued passionately for research on human embryonic stem cells to help those - like his father Ronald, the late Republican president who are cruelly struck down by degenerative diseases. Kerry built on that theme. And in her speech, his wife, Teresa Heinz Kerry, lauded NASA's Hubble Space Telescope and its Cassini mission to Saturn. Democratic strategists have evidently figured that there are votes to be gained in supporting science, and that this is an area of policy in which President George W. Bush is perceived to be weak.

The Bush administration has been heavily criticized in scientific quarters. In the spring, the left-leaning Union of Concerned Scientists (UCS) received favourable media coverage when it slammed the Bush administration for stacking advisory committees with its supporters and ignoring advice that runs counter to its ideology. The UCS report was accompanied by a statement from 62 prominent researchers calling on Bush to put a stop to the "politicization of science".

Many Republican politicians saw the statement - occurring as it did, in an election year — as a political act in itself. And in June, 48 Nobel laureates took things a step further by publicly endorsing the Democratic contender. "John Kerry will restore science to its appropriate place in government and bring it back into the White House.
He is the clear choice for America's next President," they wrote. Now, like-minded scientists are planning to form a new group, Scientists and Engineers for Kerry, in the hope of swinging the election in favour of the Democratic hopeful (see page 595).

In the current polarized political climate, it is hardly surprising that some scientists should swing behind Kerry in this way the research community traditionally votes overwhelmingly Democratic. But the emergence of science as an election issue presents opportunities that cut across the lines of partisan party politics.

Most researchers are not overtly political animals. They are more comfortable arguing for a policy that they believe to be based on sound science, rather than campaigning for one party or another. For the time being, Kerry is making the running on scientific issues. But if his advisers are correct in their judgement that the public is receptive to a pro-science message, it won't be long before the Bush campaign is seeking to build bridges with the scientific community.

Scientists, regardless of their political affiliation, should take advantage of this course of events. Whoever wins or loses, scientists have an opportunity to raise the profile of research nationwide. And they may cause whoever triumphs in November to think more deeply about how they will use science in their administration.

Above all, researchers should remember that the last election was decided by just 537 votes in Florida - less than one-eighth of the number of scientists who have so far signed the statement backing the UCS report. Both Bush and Kerry should be reminded that, in a close-run poll, science-friendly policies could help swing the balance between defeat and victory.

\section{Weak at the centre}

\section{Germany's obsessive federalism has become an anachronism that is holding back the nation's science.}

$\mathrm{T}$ o those outside Germany, it seems inconceivable that a failed attempt to discard an archaic academic qualification could displace the tragedies of Iraq and Sudan from the news headlines. But it happened last week, after Germany's constitutional court ruled that the central government had no right to tell the country's states, or Länder, how to run their universities (see page 599).

The ruling has a wider political significance. In 1949, Germany's postwar constitution handed primary responsibility for many areas of policy to the Länder, to prevent anyone from emulating Adolf Hitler's rise to supreme power. Today, however, this decentralization has become a handicap to Germany's competitiveness.

The current débâcle surrounds attempts to replace the outmoded Habilitation, a post-PhD qualification traditionally required for progress in German academia. The mess arose from a laudable attempt by federal research and education minister Edelgard Bulmahn to modernize the German academic system by establishing 'junior professorships' as an alternative. But three conservative Länder objected to Bulmahn's intervention in the affairs of their universities, and took the case to the constitutional court.

What's most depressing is that the three Länder have nothing against the idea of providing independent positions for talented young scientists - they were just defending turf. And this isn't an isolated example: last month, Länder governments delayed, perhaps for ever, the introduction of $\mathrm{€} € 1$.9-billion (US\$2.3-billion) windfall to upgrade some universities to 'élite' status (see Nature 430, 283; 2004). Before the money is handed out, they wanted the relevant responsibilities of the central and Länder governments to be clarified by a high-level'federalism committee', which was set up last autumn.

Conservative Länder politicians — led by Edmund Stoiber, prime minister of Bavaria and co-chair of the federalism committee are now pushing to scrap a 1976 law that shares responsibility for science and higher education between the Länder and the central government. They want to devolve more power to themselves.

This would be a retrograde move. If individual Länder draw up their own policies on academic career development, moving between universities in Germany could become as complicated as going abroad. The German academic system could degenerate into a series of inward-looking institutions, none of them able to compete on the international stage. What German academia needs is more centralized strategic thinking, not less. 